\title{
The Explanatory Comparison of Religious Policies in Central Governments of Safavid and Qajar Dynasties (1521.1925-AD)
}

\author{
Kourosh Hadian ${ }^{1}$, Morteza Dehghannejad ${ }^{1}$ \& Aliakbar Kajbaf $^{1}$ \\ ${ }^{1}$ History Department, University of Isfahan, Isfahan, Iran \\ Correspondence: Kourosh Hadian, History Department, University of Isfahan, Hezarjarib Strezarjarib st. ityeet, \\ Isfahan, Iran. Tel: 98-913-300-5202. E-mail: sasanirani41@yahoo.com
}

Received: May 7, 2012 Accepted: June 15, 2012 Online Published: July 1, 2012

doi: $10.5539 /$ ach.v4n2p182

URL: http://dx.doi.org/ 10.5539/ach.v4n2p182

\begin{abstract}
The attempt is made in this article to analyze and compare the religious policies of the two Safavid and Qajar dynasties' governments with respect to Sunnite sect. In these eras the related policies differed although the official religion of both regimes was Shiism: The Safavid central government's confronting policies against Sunnite, the Sunnite elites' long-term appointments to high state ranks by Qajar Kings and these policies were more consistent in Qajar than Safavid era. Here the approaches of both the dynasties are categorized in four parameters: confronting, excommunication, discrimination and moderation. In Safavid era the first three parameters were more apparent while the fourth parameter is more evident in Qajar era.
\end{abstract}

Keywords: Sunnite, central government, Safavid, Qajar

\section{Introduction}

Here the attempt is made to compare the Safavid and Qajar dynasties' religious policies regarding Sunnite sect. The main question here is addressed as: During the ruling of Safavid and Qajar dynasties what was their central governments' attitude towards the Sunnite sect?

The hypothesis here emphasizes on the fact that both dynasties accepted the Shiism as being an official sect of the state while adopting different approaches and methods towards Sunnism. These differences revolve on the following three axis: during Safavid ruling the tendency of government is more confronting in principle and practice towards the Sunnite sect while in Qajar era the central government restrains its conduct regarding religious confrontations; during Qajar ruling the Sunnite sect elite occupied high long-term official possissions in the court and the proportionate religion policy sustainability in Qajar era compared to Safavid is distinctive.

In Safavid era the presence of Sunnitee officials in the central government is two-fold: first, the era before Shah Abbas era when Kurdish Sunnite officials presence in the central government is evident and their number reaches its peak during the short-lived Shah Ismail the second's ruling; the second covers the beginning of Shah-Abbas the first's era to the end of Safavid era where the Sunnite officials presence was low in the government.

During the Qajar era that had the experiences of, Afshar and Zand dynasties specially Nadir Shah Afshar's religious revisionist policies, the persistence on Shiites slogans was evident while the sensitivity towards Sonnies was not as tense as Safavid era and less concern is directed towards Sonnies elite presence in the government. In this respect the proportional sustainability of Qajar era can be considered as an outstanding trait.

Another obvious difference in Qajar and Safavid was the reformist approach of the Qajar governance towards Safavid methods in their interaction with the Sunnitees. In Qajar era the harsh interaction among the authorities was not outstanding in some Shiite ceremonial events disregarding the Sunnite faith is not promoted by the government but measures were adopted to restrict any insult towards Sunnite sect. Despite all these the bitter look towards the Sunnites, something inherited from Safavid era, is evident among the mass of the people.

Unlike Safavid in Qajar era, a Sunnite government official could openly reveal his religion, even at the highest levels; Aziz Khan Mukri is a sample, a Kurdish official who kept office for a long time. 


\section{Approaches}

The stablishment of Safavid dynasty and the legitimacy of Shiite sect coincided. At this point the Shiite faith is not spread enough to cover the whole country and the ruling dynasty faced problems in promoting Shiite even having human resources, management, and clergies etc. at its disposal.

The political conditions of the region consisted of two Sunnite, the Ottoman Empire in the west and Uzbeks in the east, in a sense exposing the Shiite Safavid to a risk.

The Sunnite issue, regarding the formation of Qajar dynasty is different from that of Safavid. On one hand, Qajar accepted Shiite and on the other hand, the changes and reforms on religion by Nadir Shah Afshar who emphasized on fine tuning of some religious policies of Safavid era. The majority of the population had a tendency towards Shiism. In addition, the regional and global political condition had changed a lot and presence of powers like Russia, Brittain and France in the region and the proportional loss of Ottoman power, the greatest Sunnite State, paved the way for political and military correspondence.

It seems natural that the government approaches in this era was pregnant with differences; the historical evidences would be presented and discussed as we progress.

\subsection{The Confronting Approach}

The approach adopted by Safavid Kings against the Sunnites was confronting. The historical facts and records (NavidShirazi, 1991: p 42. Qomi,1985,vol.1: p 113) reflect this approach, which was intensified during Shah Ismail the second's ruling period and after Shah Abbas the first it lost intensity to a degree. The Safavid had accepted Shiite as the national official religion and the rulers adopted the promotion of this sect by force and confrontation policies against Sunnites; moreover, at the beginning of their ruling the Safavid Kings tried to convert Sunnites to Shiite. One of the outstanding religious conflicts was the Sarakhs war between Abbas Mirza and some Sunnite Turkaman tribes where Abbas Mirza won. (Hidayat, 2002, vol.9: p 1989)

Regarding Afghanistan the religious differences are more evident. In this region the confrontation between the central government of Iran with the people of Ghandehar (Itizad al-saltaneh, 1992: p 471) and the confrontation during concurrence of Herat by Muhammad Shah Qajar's (Jahangir Mirza, 2006: p 257) showed high caliber confrontation of the Sunnite population of both cities against Qajar forces and exhibit the intensity of religious policies implementation. The Qajar era is significantly different in this respect.

\subsection{The Excommunication Approach}

This approach was apparent to the state authorities and was focused on in internal and external dimensions of Safavid governance. In this respect the Shiite and Sunnite sects considered themselves as the righteous and the other the null and void. In all the official correspondence between Iran and Ottoman Empire and Uzbak Kings this issue is highlighted. The neighboring Sunnite states considered the Safavid regime as a evidence of blasphemy and raging a war against the Safavid would be called a "Jihad against the opposers of religion" (Navaei, 1972: p 314).

An anti-Sunnism idea was prevalent in Safavid court in the same period. According to Shiism any sect outside the Shiite realm was considered non-Muslim and to them Sunnite believe was "the legions of null and void" (Husayni, 2001: p 179).

This conflict reaches its peak in some segments of Shah Tahmasb and Sultan Muhammad Khudabanda's ruling according to mutual communiqué between Iran and Ottoman (Navaei, 1972: p 37). According to Safavid all sects other than Shiite are outride Islam framework to a degree that the city of Istanbul was called the city of "null and void" by Shiites. (Navaei, 1972: p 234)

In the Qajar era the samples of excommunication approach are rare and ignorable (Hidayat, 2002, vol.9: p 7763) so not many documents are found.

\subsection{The Discrimination Approach}

In parallel to the elimination policy, Safavid governance practiced discrimination in order to influence the decision making process regarding religious sects' faith. This attitude was evident through advantages provided to Shiites like discount in taxes, facilitating official needs etc. (Sadeqi, 1948: p 292), providing preferred educational and recreational facilities to Shiite neighborhoods, something that was nonexistence for the Sunnite(Turkman,1960, vol.1: p 123). A distinct evidence in this respect is one of Shah Abbas the first's decree on attesting the property endowment where in the document the following expression is expressed for three times "receivers of these properties must be of orthodox Shiite sect"(Shamloo,1993,vol.1: p 190). Conversion to 
Shiite was a measure taken by some Sunnite provisional governors where they would become subject to discounts on taxes and judicial convictions. (Turkman, 1960, vol.2: p 470,502).

\subsection{Moderation Approach}

Some elements of moderation that were less hardline approach in Safavid era can be observed that were interpreted specified with as an acceptance approach: i.e both Shiites and Sunnites are Muslim and religious policies should be adopted as being common in both sectarian beliefs (Navai, 1975, vol.2: p 206). Here the forces of the both sectors, at least in theory can fight against, nonbelievers and follow Jihad for God. Purity and single orientation replaced hate to a point that a high ranking Sunnite official in Safavid court wished to serve in Ottomans Army against non believers and with the "victory to Islam Army and down with the null and void army" prayer he went to Mashhad and every one in Iran prayed for the Sunnite warrior to concur the enemy (Navaei, 1988, vol.3: p 215).

Tahmasb the first rejected entering war with Ottoman Empire and justified this action emphasizing that Muslims sectors should not engage them in war and it is not a Godly act. This response is another fact supporting the "purity and single orientation" concept (Husayni, 2001: p 121).

This concept is reflected and highlighted in the mutual religious differences treaties where repudiation of either of the sects is strictly disallowed. Sultan Murad the third, applied for a conditional peace based on restriction of cursing prophet's companions and Caliph's and abolition of repudiation and Safavid court takes advantage of deductive reasoning rather than anathematizing.(Navai,1975,vol.2: p 105,109 )

It is possible that the Safavid King influenced by some political issues, in certain stages had recognized he should kind of ignore the sectarian conflicts and focus on axial concepts of Islam that would unify Ottoman Empire and Iran under Islam realm.

It seems that in Sfavied Governance the relations with Sunnite states the principle approach was based on anathematizing and confrontation and the accord was only in certain areas on conditional bases.

In Qajar era the moderation approach was more prevalent. The King himself established casual relation with the Sunnite's elite families and respected them. He also took a Kurdish Sunnite Sheikh's daughter as his wife. Abass Mirza Molkara is one of the King's sons from this wife. Muhamad Shah was influenced by this wife and respected the Sunnite Sheikhes and gave them annual presents (Mulkara, 1977: p 17).

It is recorded that the King, on his trip to Khurasan paid homage to Sheikh Ahmad Jam Jendepil's tomb (Hidayat, 2002, vol.10: p 8211). In this era some behavioral modifications were observed and a reduction in conflict is noticed. Due to agreement with Ottoman state the Iranian Shiites gained more freedom outside Iran. According to Itimad al-saltaneh any state ran through religious hardliners is ran by ignorant; therefore, the state is trying to correct such approaches since religious fanaticism has negative effect on Islam in general. He also has pointed out that Nasir ud-Din Shah ordered the hardliner religious leaders to control the publications and prevent any statement that would be considered offensive to Sunnism (Itimad al-saltaneh,1985,vol.1: p 177); Hidayat has pointed to the same issue and the negative consequences there for Islam, if not controlled or prevented. (Hidayat, 2002, vol.10: p 8740)

These are the samples of the critical behaviors' comparisons between Safavid and Qajar eras at least at the elite level and a calmer period is sensed under Qajar era. In Safavid era anti-Sunnite movements were promoted by the state while in Qajar era the movement was demoted. Of course, outside the elite circle at the lower stratum the conflict flame was not extinguished among ordinary believers. According to (Wills, 1988: p 281) a foreign observer, there existed some religious ceremonies organized by Shiites that offended the Sunnites.

\section{Sunnite Appointed Officials in the Government}

This phenomenon is Safavid era consists of two periods.

\subsection{The First Period, from Beginning of Safavid Era to Shah Abbas the First}

Here Sunnite elite officials in the central government is observed with posts like governor of Gilan, Sharaf-Khan Bedlisi during Shah Tahmasb's ruling (Qomi, 1985, vol.1: p 477). During the short period of Shah Ismail the second this trend almost reached its peak, where Mirza Makhdum, the sage, was appointed to premiership (Turkman, 1960, vol.1: p 148) and Sharaf Khan Bedlisi in the same period was promoted to the state trustee (Bedlisi, 1995 : p 581).

It appears that the presence of Sunnite elite at some levels of Safavid era during Shah Tahmasb the first was influential (Qazvini, 1999: p 81). Here it should be mentioned that in the daily court life the seat setting was such 
that the Sunnite elite had to be placed at the end of the table that indicate of lower ranking. (Falsafi,1993,vol.3: p p1260)

The ambiguity exists that whether the rulers by knowing the appointees being of Sunnite sect still agreed with their position in the system or not and what indicated the glass ceiling in the Sunnite elite's promotion? Could it be assumed that in general the Sunnites.

At the beginning of Safavid era and official recognition of Shiism by the state, it was not spread all over the country and the state did not have enough missionaries and skilled politicians in order to free itself from Sunnite elite; therefore it had to cope with the Sunnite statesmen. This was particular to the Shah Ismail the first and Shah Tahmasb eras and as mentioned above the Sunnite elite presence cannot be related to the requirements of the Safavid regime.

Three concepts are addressed towards religious tendency and practicality regarding Shah Ismail the second: First his tutor was of Sunnite sect (Navai, 1974: p 137) and he wanted to promote Sunnism although he pretended to be a Shiite (Falsafi, 1993, vol.2: p 49). Second, his twenty years imprisonment had a negative effect on his emotions and he wanted to convert to Sunnism (Hinz, 1993: p 113). Third, he had a tendency towards religions in general and the extreme behaviors towards Sunnism by the government did not fit his believes and political format. Due to this fact he is called "the first and the last liberal King of Safavied era regarding religion" and this in a sense promoted dissatisfaction about himself from different influential levels in government such as Qizilbash and Shiite elite (Parsadoust, 2003: p 159).

Promoting some of the competent elite who were in seclusion due to their being of Sunnite sect and demotion and dismissal of some Shiite elite that caused their migration are the concrete evidence of what he did with respect to religion.

\subsection{The Second Period, after Shah Abbas the First to the End of Safavied Era}

In this period the attempt is made to replace the Sunnite governors with Shiite and reduce the number of Sunnite elite in the top ranks of the government. He did allow Ahmad Khan Ardalan to marry his sister with the condition to promote him the governor of Kurdistan. Halukhan, Ahmad khan Ardalan's father who governed Kurdistan was a Sunnite became worried of the decision made by the king, by reasoning that the Shiism could be promoted through his son in Kurdistan (Babani, 1999: p 44).

Another fact among many is that the Kurdish Donboli tribe who resided in Khuy since Shah Tahmasb's ruling era converted to Shiism in Shah Abbas the first's era (Riahi, 1994: p 130).

Some researchers are of the opinion that the religious policy of Safavid dynasty regarding provincial governments was based on converting the Sunnite local governors to Shiite whether by will or force (Born, 1997: p 143). Of course this approach could be mostly assigned to Shah Abbas the first's era since a significant difference was noticed in his character, political power and planning and executive skills in that of the same among the Kings that followed him.

After his era the presence of Sunnite elite at the government top ranks was very low. Only during Shah Sultan Husayn in 1715-AD, one Sunnite elite named Fath Ali Khan Dagestani occupied a ministers' position (Husaynikhatunabadi, 1974: p 569). His skills and strategies are verified by the historians (Marashi, 1984: p 30), but the fact that he was Sunnite provoked the courtiers and the King's attitude against him to a point that he was stripped off his duties and punished by being accused of planning espionage against the Shah, a false accusation (Marashi, 1984: p 49). His presence in Safavid court was sincere with no propaganda on Sunnite sect. His abilities and knowledge in management was high, something that his friends and enemies admit and this honesty led to competition and jealousy in the court against him. This is another indication that as Safavid era approached its end, the system became more sensitive towards the Sunnite political elite to a degree that even carrying Sunnite label meant dismissal from the court.

In Qajar era more Sunnites were appointed to different offices at state and provincial level. Due to lack of proper knowledge about the appointee, sometimes the Sunnite official in charge would cause serious problems for the system. In 1841-AD, Haji Khan Shaki a very prejudice Sunnite statesman was appointed to govern Khuzistan province. He entered a conflict with the Shiite residents and this led to a battle that many were killed and many fled to Ottoman (Itizad al-saltaneh, 1992: p 529). On the other hand there was Aziz Khan Mukri who past his life in Qajar court occupying different posts like provincial leader, minister of war and minister of foreign affairs. He carried his Sunnite faith and everyone knew that. In general during Qajar ruling the strong prejudice views against domestic Sunnites and Sunnite states neighboring Iran had diminished, of course scattered conflicts among the population was inevitable. In a sense the central government was trying to prevent any conflict in this 
regard. Back then about seven percent of the population in Iran were of Sunnite faith who lived in strategic regions-west, North-West, south and east of Iran (pulak, 1983: p 240), although proportionally more Sunnite statesmen were occupied in the state.

\section{Managing Sunnite Populated Regions and the Expansion of Sunnites' Protests}

The haphazard policies adopted for Sunnite regions management at the end of Safavid era is a negative point to a degree that the appointee's strict behavior with other religious minorities such as Shafeiis (Qazi,2001: p 38) would end up in domestic tribal uprising and migration (Savery,1997: p 69). Records show that the Kurd elite had asked the state to send Kurd governors of Ardalan tribe because in Kurdistan this tribe was a majority (Qazi, 2001: p 39). A similar conflict was recorded in the same period with the same conditions in Qandahar region. This sensitive bounder region was assigned to Gorgin Khan a man with not so good background in governing (Nasiri, 1995: p 273). His appointment was a failure because he not only did not control the potential regional conflicts but discouraged the enthusiasm of fighting the Qizilbash army and contributed to that army's collapse according to the discerning historian's records. Consequently, the Sunnite Afghans' hatred towards Qizilbash stirred up and the central government became so confused that when Mirveis issued a complaint, it was not only dealt with justice but caused his imprisonment and death treat since the policy makers imprudently emphasized on his exit from the system (Marashi, 1984: p 3 \& 15).

Mirveis eventually set up to Hejaz. There he reported the Sunnite Afghans' condition to the Sunnite elite complaining that non-Arab Kings are the enemies of the companions of Prophet and are heretics, he also complained about the endless encroaching and the cursing the triad companions of the Prophet. Here he was able to obtain the religious decree on holy war and the lawfulness of taking spoils and shading blood of the heretics (krosinsky, 1985: p 23) along with the necessary religious legitimacy measures in the future (Savory, 1997: p 243).

At the end of Safavid era the religious conflicts reached their climax among which the Shirwan confrontations where numerous Sunnite and Shiite believers were killed (Leckhart, 1990: p 148), the four year crisis in Baluch region and Turkamans uprising in Estarabad (Nasiri, 1995: p 205 \& 243), and the slavery of thousands of Shiite of both genders by the Uzbaks (Marashi, 1984: p 23) are the outstanding ones. kandahar conflict tops these all, and it can be a warning singe in shaping up of political, social turmoil based on religion tone.

\section{Conclusion}

From the historical indications presented in this study it could be deduced that in both the Safavid and Qajar eras although the legitimacy of the governance was based on Shiite sects teachings and had to be promoted and expanded by both the dynasties, the differences in implementing the promotion plans regarding the constraints towards Sunnites is obviously observable at the state level.

In Safavid era the general approach regarding conversion of Sunnites to Shiite was of confrontation except the short leaved ruling period of Shah Ismail the second.

In Qajar era the religious policies was more stable regarding Sunnites and the general approach was of moderation.

Comparing these two eras shows that the harsh restrictions imposed by Safavid on Sunnites are diminished in Qajar era and Sunnite elite occupies important posts in the government, ever though they admitted on their being Sunnites, unlike Safavid era.

\section{References}

Babani, A. Q. (1999). Siar Al-Alakrad (2nd ed.). Edited by Muhammad Rauf Tavakoli, Tehran: Tavkoli.

Bedlisi, S. K. (1995). In M. abbasi (eds.), Sharfnameh: history and jeography of Kurdistan (3rd ed.). Tehran: Hadis.

Born, R. M. (1997). Provinyen Und Zentralgewalt Persin. Tehran: Nashr-e Ketab.

Falsafi, N. (1993). Shah Abbas the First (5th ed., Vol. 1 \& 2) .Tehran: Elmi.

Hidayat, R. Q. (2002). In J. Kianfar (eds.), Ruzat-al-safay-e Nasiri. Tehran: Asatir.

Husaynei, K. (2001). In A. H. Navaei (eds.), Tarikh-i Ilchi-e Nezamshah. Tehran: Cultural Society.

Husayni, X. A. H. (1974). Vaqaye-Al-Senin va Al-Aavam. Tehran: Islamie.

Hinz, W. (1993). Shah Ismaeil the Second. Tehran: Elmi-Farhangi. 
Itizad al-saltaneh, A. Q. (1992). In J. Kianfar (eds.), Eksir al- Tawarikh: history of Qajar from begining up to 1843. Tehran: Hadis.

Itimad al-saltaneh, M. H. (1985). In I. Afshar (eds.), Al-maasir va al-asar (Vol. 1). Tehran: Asatir.

Krosinski. (1985). Ibrat-nameh. Tabriz: faculty of literature and human sciences.

Lockhart, L. (1990). The fall of Safavi dynasty and the Afghan occupation of Persia (3rd ed.). Tehran: Murvarid.

Mulk, A. A. (1977). In A. H. Navaei, biography of Abbas Mirza Mulk Ara (2nd ed.). Tehran: Babak.

Marashi, M. K. (1984). In A. Eqbal (eds.), Majma-al-Tawarikh. Tehran: Tahuri, Sanaei.

Nasiri, M. I. (1995). In M. N. Moqadam, Dastur-e shahryaran. Tehran: Afshar Yazdi.

Navaei, A. H. (1972). Shah Tahmasb, historical documents . Tehran: Culture Institute of Iran.

Navaei, A. H. (1974 a). Shah Abbas the first, historical documents (Vol. 1). Tehran: Culture Institute of Iran.

Navaei, A. H. (1974 b). Shah Abbas the first, historical documents (Vol. 2). Tehran: Culture Institute of Iran.

Navaei, A. H. (1988). Shah Abbas the first, historical documents (2nd ed., Vol.3). Tehran: Zarrin.

NavidiShirazi, Z. (1991). In A. H. Navaei (eds.), Takmelat-al-Akhbar: History of Safavid from Beginning up to 1561. Tehran: Ney.

Parsadoust, M. (2003). Shah Ismaeil the second. Tehran: Enteshar.

Polak, J. E. (1983). Persian, dus land and seine. Tehran: Kharazmi.

Qazi, M. S. (2001). Zubdat-al-Tawarikh-i sanandeji. Tehran: Tavkoli.

Qazvini, B. (2000). In M. Bahramnejad (eds.), Javaher-al-Akhbar: history of Safavid from beginning up to 1576. Tehran: Miras-e Maktub.

Riahi, M. A. (1994). History of Khuy. Tehran: Tous.

Sadeqi, K. (1948). Tadhkiriy-e Majma al- Khavas. Tabriz.

Savory, R. (1994) Iran under the Safavid. Tehran: Markaz.

Shamlu, V. Q. (1993). In H. S. Naseri (eds.), Qesas-al-khaqani. Tehran: Ministry of Islamic Guidance and culture.

Turkman, I. M. (1960). Alam Ara-ye Abbasi. Isfahan: Taeid.

Wills, C. J. (1988). In J. Dudange, \& M. Niknam (eds.), Persia as It Is: Being Sketches of Modern Persian Life and Character (2nd ed.). Tehran: Tolu. 